\title{
THE NEW AMERICAN CODE OF LEGAL ETHICS.
}

It was natural that the general trend of public opinion in this country in favor of codification, as against unwritten law, should of late years turn the attention of the bar to the question whether the rules of legal ethics ought not to be put in an authoritative form. In a number of the States steps have been taken in this direction, and the last Summer has given us a code stamped with the approval of the American Bar Association. It is the work of a strong committee, which has proceeded slowly and carefully. The task assigned to them was no easy one. It was that of definition and selection. Omnilis definitio periculosa est; and to select means to exclude-always a difficult thing to do to general satisfaction, where questions of morals are concerned.

One is struck, in reading the brief code which has been thus elaborated, by the extent to which the policy of exclusion has been carried. Nothing is to be found as to the duties of the Judge; and little as to many minor matters pertaining to a lawyer's conduct. In both these respects the action of the Association seems wise.

It is an association of members of the bar, as its name denotes. A Judge does not, in becoming such, cease to be a lawyer; and therefore many of them belong to it, and take an active part in its proceedings. Justice Brewer was upon the committee which framed this code. But it is rather for courts to lay down rules for the bar, than for the bar to prescribe them for the courts. If Judges need to be reminded of their duties, some of their number should assume the task, and it should be wholly dissociated from any rules as to the conduct of those who may practice before them.

The codes of ethics thus far adopted by the State Bar Associations are considerably longer than that now approved by the American Bar Association. They contain more rules, and more words in stating a rule.

They frequently seek to fortify a canon of conduct by subjoining an argument for following it. The reasons given are generally those of policy. Follow it, they argue, because you will succeed better in your profession, if you do. Avoid concealing your strong points until the closing argument, because the court and jury will think you must have a weak cause, if you resort to such a course. Do not assert your belief in the justice of your client's cause, because if you do for one, you must do it for all; 
else the jury will think that, whenever you omit such a statement, you know that your claims are unfounded. Be prompt and punctual, and it will strengthen your hold on your clients.

The new code of the American Bar Association makes no such appeals to motives of expediency and self-advantage. It occupies a higher plane. Its canons are left to rest on principles of right and honor. The only exception, if it can be deemed such, is the declaration in the preamble that the future of our country depends upon the maintenance of Justice pure and unsullied, and that this can only be secured if the conduct and motives of the American lawyer merit the approval of all just men. But here the good of the republic is looked at, not that of the individual.

One canon of great importance has been adopted which is to be found in the code of no State Bar Association except that of Kentucky, and is there stated with much less force and precision. This expresses the duty of the bar with respect to the choice of Judges. It is asserted to be an active duty; and in that connection one rule of conduct is mentioned which all accepting judicial office should be expected to follow. It is to forego all other employments whatsoever which might embarrass their free and fair consideration of questions brought before them for decision.

To mention but one reason for insisting on this obligation, it is one of the petty scandals of our American judicial system that a Judge of a minor court, provided with several Judges, sometimes appears as counsel one day and as Judge the next. Obviously, one who has argued before such a tribunal in favor of a debatable legal proposition ought not, at the same term, to charge a jury in respect to it. Nor could his refusal to preside over the trial of a cause in which that question might arise relieve the difficulty of the situation. It simply substitutes one wrong for another. The public have the right to demand that he shall not disqualify himself from doing what he was appointed to do, and inconvenience others to profit himself.

It is to take a long step forward for the representatives of the American bar to declare that it must steadfastly endeavor "to prevent political considerations from outweighing judicial fitness in the selection of Judges" and "should protest earnestly and actively against the appointment or election of those who are unsuitable for the Bench." In the political discussions of the last few years, the American judiciary has been a frequent subject of attack. There is no doubt that among its members are some who are incompetent to undertake its responsibilities, and who, when appointed or elected, 
were known to be thus incompetent by the members of the bar to which they belonged. The appointing power or the electorate, if the choice be by popular vote, will seldom, if ever, select a man whom his professional associates come forward to declare to be unfit to exercise the duties of such an office. In asserting it to be their duty to make such declarations, in the proper quarter, be it in the office of the Governor, or in a nominating convention, or in a preliminary meeting of the party leaders, or by addressing the public at large, this new canon ought to have a large and lasting effect. In no country is the Judge so fully a part of the political administration of civil government as in the United States, because nowhere else has he such a power of declaring statutes to be void. In no country, therefore, can the bar, by preventing improper selections for judicial office, do so much to promote the proper transaction of public business, as well as the proper protection of private interests.

The code occasionally contains general expressions which in practice must be taken with certain implications or limitations.

Thus $^{1}$ it is stated that money of the client coming into the possession of the lawyer should not be commingled with his' private property or be used by him. This can hardly be meant to treat it as a breach of ethical obligation for an attorney of ample means, who receives a bank check in payment of a claim left with him for collection, to deposit it to his own credit in his own bank account, in order conveniently to deduct his own fees, remitting the balance promptly by his own check to the client. It would seem in foro conscientice (whatever might be the lawyer's liability, should the bank fail) that the client's consent to such a transaction would be fairly implied, even if there had been no previous dealings between them of a like nature. So the young lawyer who receives a five dollar bank note to apply on a claim for a hundred dollars can hardly be regarded as in the wrong, if he puts it for safe keeping in his own pocket-book, provided it be with the intention of paying over the sum due at the first reasonable opportunity, although it might not, and naturally would not, be so paid by the delivery of that particular bill.

Other articles must be read with some care, as a whole, in order to get at their true meaning.

Thus Article 27 declares that the "publication or circulation of ordinary simple business cards" is not per se improper, but that

${ }^{1}$ Article II. 
"solicitation of business by circulars or advertisments" is unprofessional. Here "publication" would seem to include and certainly should include a publication in a newspaper of such a card as a paid advertisement. The distinction which it was intended to draw would appear to be that between advertising the fact that one is a lawyer and does business at a certain place or at certain hours, and an advertisement in which, besides this, business, or business of a certain kind, is solicited.

So Article 28, after declaring it to be disreputable for a lawyer to hunt up causes of action in favor of those who are ignorant of them, in order to obtain employment to bring suits; to be an ambulance-chaser; "or to pay or reward, directly or indirectly, those who bring or influence the bringing of such cases to his office, or to remunerate policemen, court or prison officials, physicians, hospital attachés or others who may succeed, under the guise of giving disinterested friendly advice, in influencing the criminal, the sick and the injured, the ignorant or others, to seek his professional services," proceeds to state that it is the duty of any member of the bar "having knowledge of such practices upon the part of any practitioner, immediately to inform thereof to the end that the offender may be disbarred." Here the words "such practices" are apparently to be limited in their application to the last of the class of acts which have been censured; for disbarment would, except under extraordinary circumstances, seem to be too heavy a penalty for the others.

The canon regarding contingent fees was the only one amended in substance, by the Association, in dealing with the report of the Committee, and indeed it is not clear that this amendment changed anything but the form, so as to make plainer what was the intention of those who drafted it. In its present shape it seems to sanction, by implication, arrangements for contingent fees (when not contrary to the local law), provided their terms are reasonable; and its real emphasis is laid on the necessity of providing a prompt remedy for the client by the supervisory action of the court, if any unfair advantage of his necessities has been taken. Precisely how this supervisory action should be invoked was left to be decided by the local practice; and it would have been difficult to frame any form of procedure of universal application.

One question of professional obligation, as to which the practice at the English bar might be misleading, has been definitely and properly settled ${ }^{2}$ : An American lawyer is free to decline

${ }^{2} \mathrm{By}$ Article 3r. 
any retainer. There may be a reason for denying such a right to the English barrister. His retainer comes through the hands and at the instance of another legal practitioner, who presumably has satisfied himself that the action ought in justice to be brought or defended, as the case may be. To refuse to accept it would reflect on him. With us, where the client comes or can with propriety come directly to him whom he wishes to advocate his cause, such considerations of fraternity or professional etiquette have no place.

The committee had before it an important suggestion from Justice Brewer that a short body of rules should be prepared to be "given operative and binding force by legislation, or the action of the highest courts of the States," where that should be within their powers. It concluded not to urge such an endorsement of the code, as a whole, but, instead, drafted a form of oath to be taken on admission to the bar, which the Association by its action has now recommended "for adoption by the proper authorities in all the States and Territories." This form is mainly taken from that prescribed in the State of Washington, which was itself founded to a considerable extent on that in use in the Swiss Canton of Geneva. Both these, however, were subject to serious criticism in that they contained a pledge to counsel or maintain such proceedings only as should appear to the affiant to be just, except in the defence of one charged with crime. This forces the lawyer into the position of a Judge, before the case has been brought or heard. He must be satisfied that a suit or defence is just, before he can take the first step in court. The form recommended by the Association gives the provision in this respect a different turn. The affiant pledges himself not to counsel or maintain any suit or proceeding which shall appear to him to be unjust, nor any defence except such as he believes to be honestly debatable under the law of the land. The burden assumed as to actions is not to satisfy oneself that a suit is just, before bringing it, but not to bring it if satisfied that it is unjust-an obligation much less onerous; while as to defences it is enough if they seem to him honestly to present a question which, under the law, may be fairly made a subject of discussion on the trial. In both cases, the client has the benefit of the doubt.

This seems right. A lawyer should decline a retainer to accomplish what appears to him, after due consideration, to be a piece of injustice, but, if it does not so appear, that is, if after due 
consideration he is not of the opinion that the cause or defence which he is asked to advocate is unjust, the question becomes one which ought to be decided by a court, after hearing both sides, if the party interested desires a judicial determination. The oath used in some of the Germanic States is framed upon similar lines.

In another point the Washington form has been changed to advantage. Following the ancient Geneva pattern, it pledged the affiant never to seek to mislead or deceive the Judge by any artifice or falsehood. This may have been sufficient in a country having no system of trials by a jury, but the committee, in view of the prevalence of that system here, properly added the words "or jury" after "Judge."

One addition to the form is of more doubtful merit, because it refers to a practice which can never be of common occurrence, while it would seem that a lawyer's oath of office should be confined to obligations of fundamental importance and general concern. This is a pledge that the affiant will accept no compensation in connection with a client's business, except from him or with his knowledge and approval.

Another addition taken from the ancient New England form, dating back to early colonial days, is a pledge not to delay any man's cause for lucre and malice. This, again, must be construed in view of what precedes it. If a client desires delay for a legitimate reason, to accept remuneration from him for securing it by taking advantage of some legal right can hardly be deemed reprehensible. To delay his client's cause, on the other hand, in order to increase his own fees, would be obviously wrong.

It might be too high praise to say that this code, as finally approved, could not have been made better. But the question for the American lawyer is not whether a more perfect one could be made. It is whether this code, having been framed after long deliberation and extensive correspondence by a capable committee representing all parts of the United States, and adopted with practical unanimity, after full opportunity for discussion, by the American Bar Association, ought not, as a whole, to receive his support.

If this code is accepted by the Bar Associations of every State, as a fair general statement of the main duties of members of the legal profession, a great purpose will be well accomplished. An authoritative criterion will be supplied, by which every lawyer can be safely guided, when he is in doubt as to the conduct he should 
pursue in respect to any of the questions which oftenest prove a source of perplexity. The law student will have a mentor, always at hand. The courts will hesitate less in enforcing the discipline of the bar, since professional misconduct will be, more than ever before, a sinning against the light.

New Haven, Conn.

SiMEON E. BALDWIN. 